\title{
Reducing Ultra-Clean Transportation Fuel Costs with HyMelt ${ }^{\circledR}$ Hydrogen
}

\author{
Quarterly Report
}

July 1 - September 30, 2004

October 2004

Work Performed Under Cooperative Agreement No. DE-FC26-02NT41102

For

U.S. Department of Energy

National Energy Technology Laboratory

P.O. Box 10940

626 Cochrans Mill Road

M/S 922-273C

Pittsburgh, PA 15236-0940

By

Donald P. Malone and William R. Renner

EnviRes LLC

1517 Bull Lea Drive

Suite 200

Lexington, KY 40511 


\section{DISCLAIMER}

This report was prepared as an account of work sponsored by an agency of the United States Government. Neither the United States Government nor any agency thereof, nor any of their employees, makes any warranty, express or implied, or assumes any legal liability or responsibility for the accuracy, completeness, or usefulness of any information, apparatus, product, or process disclosed, or represents that its use would not infringe privately owned rights. Reference herein to any specific commercial product, process or service by trade name, trademark, manufacturer or otherwise does not necessarily constitute or imply its endorsement, recommendation, or favoring by the United States Government or any agency thereof. The views and opinions of authors expressed herein do not necessarily state or reflect those of the United States Government or any agency thereof. 


\section{ABSTRACT}

This report describes activities for the seventh quarter of work performed under this agreement. We await approval from the Swedish pressure vessel board to allow us to proceed with the procurement of the vessel for super atmospheric testing. 


\section{TABLE OF CONTENTS}

1.0 Project Objectives, Scope and Description of Tasks

1.1 Introduction

1.2 Scope of Work

1.3 Phase I Task Description

2.0 Executive Summary of Work Done During This Reporting Period

3.0 Experimental

4.0 Results and Discussion

5.0 Conclusion

6.0 References

7.0 Plans for the Next Quarter

Appendix I MEFOS DATA 


\subsection{PROJECT OBJECTIVES, SCOPE AND DESCRIPTION OF TASKS}

\section{Introduction}

EnviRes and DOE executed the cooperative agreement for this work on September 19, 2002. This document is the sixth quarterly progress report under this agreement. Kvaerner, MEFOS and Siemens Westinghouse will conduct most of the significant tasks in this project through subcontracts with EnviRes.

\section{$1.1 \quad$ Scope of Work}

Phase I of the work to be done under this agreement consists of conducting atmospheric gasification of coal using the HyMelt technology to produce separate hydrogen rich and carbon monoxide rich product streams. In addition smaller quantities of petroleum coke and a low value refinery stream will be gasified. DOE and EnviRes will evaluate the results of this work to determine the feasibility and desirability of proceeding to Phase II of the work to be done under this agreement, which is gasification of the above-mentioned feeds at a gasifer pressure of approximately 5 bar. The results of this work will be used to evaluate the technical and economic aspects of producing ultra-clean transportation fuels using the HyMelt technology in existing and proposed refinery configurations.

\subsection{Phase I Task Description}

Task 1.1 Project Management and Planning

This task includes all project planning; experimental test plans; risk analysis; implementation of a bridge loan, purchasing, contracting and accounting systems with requisite auditing; and execution of contracts with MEFOS, Kvaerner and Siemens Westinghouse. This task is being executed.

Task 1.2 Preparation and Shipment of Feedstock Materials

This task consists of procuring 25 tons of coal, 15 tons of petroleum coke and 48 - 55 gal drums of aromatic extract oil; transporting the coke and coal to a pulverizing facility; pulverizing, drying and loading the coke and coal into bags; and shipping the feedstocks to MEFOS in Lulea, Sweden. EnviRes completed this task

Task 1.3 Predictive Modeling of the HyMelt Process

This task consists of generating detailed reactor energy and material balances for each feedstock using the Fact Sage pyrometallurgical thermodynamic modeling program. Kvaerner will perform detailed process simulation using the Aspen Plus process simulator. Kvaerner, MEFOS and EnviRes will evaluate and analyze the results of predictive modeling. This has been completed.

Task 1.4 Combustion Modeling and Analysis

Siemens Westinghouse will perform combustion turbine modeling using fuel gas conditions and compositions provided by task 1.3. This task is being executed.

Task 1.5 Design and Fabrication of Pilot Plant Specific Molten Iron Bath Apparatus 
-6 -

MEFOS will design and fabricate all solid feeding systems and oxygen injection systems required by the testing. EnviRes will assist MEFOS in designing the petroleum liquid feed system. MEFOS will design the shell of the high-pressure reactor. MEFOS and EnviRes completed the originally planned injection system for this task. MEFOS and EnviRes designed and fabricated a tuyere for submerged injection. MEFOS and EnviRes designed and fabricated a commercially feasible tuyere for testing in December. We performed the testing as planned.

Task 2.0 Project Testing

Task 2.1 HyMelt Atmospheric Pressure Testing in a Molten Iron Bath

MEFOS designed and fabricated the petroleum liquid feed system. This injection system was tested in a cold flow environment. The injection systems were hot commissioned. Any equipment revisions indicated by cold flow testing and hot commissioning were made. Process performance testing was performed for each feed. MEFOS and EnviRes completed execution of this task.

Task 2.4 Above Atmospheric Pressure Testing in a Molten Metal Bath

MEFOS completed a preliminary design for this work. We await approval from the Swedish pressure vessel board. When they approve the design, we will pruchase the pressure vessel

\subsection{EXECUTIVE SUMMARY OF WORK DONE DURING THIS REPORTING PERIOD}

EnviRes extended the performance period for the subcontract with Siemens Westinghouse Power Corporation to run through September 30, 2005.

\subsection{Experimental}

\section{MEFOS Activities}

No activities were performed pending approval of the pressure vessel board.

Kvaerner Activities

No activities were performed pending approval of the pressure vessel board.

Siemens Westinghouse Power Corporation Activities

No activities were performed pending approval of the pressure vessel board.

\subsection{Results and Discussion}

No experimental activities were performed during the reporting period.

\subsection{Conclusions}

No experimental activities were performed during the reporting period.

\subsection{References}




\subsection{PLAN FOR THE NEXT QUARTER}

We plan to complete the design for the pressurized converter and procure it. Kvaerner and Siemens Westinghouse activities will resume after super atmospheric data becomes available. 